\title{
Molecular Characterization and Identification of Fungi Causing Stem Canker of Oilseed Rape in Serbia
}

\author{
Petar Mitrović* · Ana Marjanović Jeromela · Željko Milovac · Velimir Radić \\ Institute of Field and Vegetable Crops, Maksima Gorkog 30, 21000 Novi Sad, Serbia
}

\begin{abstract}
Summary: During 2008-2010 the infected Brassica napus plant material was collected from nine localities: Karavukovo, Crvenka, Prigrevica, Subotica, Rimski Šančevi, Srbobran, Beška, Banatsko Karađorđevo, and Srpski Miletić. Infected tissue samples were taken from the root of both upper and basal stems, as well as from the leaf, flower and pods. Two reference isolates from Great Britain were used in these studies for the analysis of 119 isolates from Serbia, using polymerase chain reaction (PCR) and PCR-RFLP. Digestion of PCR products was performed with 5 selected endonucleases: BamHI, HaeIII, RsaI, EcoRII, and AluI. On the basis of PCR analysis, all isolates originating from Serbia belong to L. complex: 111 belong to species Leptosphaeria maculans, and 8 to species Leptosphaeria biglobosa NA1 (Leptosphaeria biglobosa brassicae), respectively.

Keywords: Brassica napus, endonucleases, isolates, Leptosphaeria maculans, Leptosphaeria biglobosa, localities, PCR and PCR-RFLP.
\end{abstract}

\section{Introduction}

Stem canker is an important oilseed rape disease in Europe, Australia, and North America (Fitt et al. 2006); and has been reported worldwide (Howlett et al. 2001; Gosende et al. 2003. The intensity of the disease depends on the climatic factors, agro-technical measures and the resistance of the varieties (Howlett, 2004; Sosnowski et al., 2004; Aubertot et al., 2006;). The disease is caused by two species of phytopathogenic fungi of genus Leptosphaeria: Leptosphaeria maculans (Desm.) ces. and de Not anamorph Phoma lingam (Tode. Fr.) Desmas, causing basal stem canker (Gabrielson 1983; Paul \& Rowlinson 1992) and Leptospaeria biglobosa Shoemaker and Brun, which causes symptoms of cancer in the upper stem generally causing less damage, while serious damage occurs in countries with higher summer temperatures (Huang et al. 2005; Fitt et al. 2006). Both species can be found in Africa, Central and South America, and Asia (Anon. 2004 cit loc Fitt et al. 2006). Based on the pathogenicity of isolates, the population of L.maculans has previously been divided into two groups - virulent and slightly virulent (McGee \& Petrie 1978; Koch et al. 1989; Badawy \& Hoppe 1989; Brun et al.1997; Williams \&

Corresponding author: petar.mitrovic@ifvcns.ns.ac.rs

Acknowledgements:

Supported by the Ministry of Education, Science and Technological Development, Republic of Serbia, Project TR 31025
Fitt 1999; Mitrović et al 2012); then into group A and B, based on RFLP analysis (Johnson \& Lewis 1990); and finally into $\mathrm{Tox}^{+}$isolates creating toxic substances phytotoxins, and $\operatorname{Tox}^{0}$ which do not reproduce toxic substances (Balesdent et al. 1992). It was determined, based on RFLP analysis and isoenzymatic analysis, that aggressive isolates form a compact group different from the slightly virulent isolates. The same methods showed that slightly virulent isolates can be divided into three subgroups: NA1, NA2, and NA3 (Koch et al. 1991, Gall et al. 1995). Gall et al. (1995) state that NA1 subgroup is predominant in Europe, whereas NA2 is more common in Canada. Balesdent et. al (1998) suggested identification of species and subspecies within the Leptosphaeria species complex, based on the ITS restrictive profile using 5 enzymes - AluI, BamHI, HaeIII, EcoRII and RsaI. Based on the obtained results, Balesdent et. al (1998) divided the Leptosphaeria species complex into 7 groups: (1.) Brassica $\operatorname{Tox}^{+}$, (2.) Lepidium $\operatorname{Tox}^{+}$, (3.) Brassica $\operatorname{Tox}^{0}$ NA1 subgroup, (4.) Brassica $\mathrm{Tox}^{0}$ NA2 subgroup, (5.) Brassica $\operatorname{Tox}^{0}$ NA3 subgroup (6.) Erysimum $\operatorname{Tox}^{0}$ and (7.) Thlaspi $\operatorname{Tox}^{0}$. On the basis of molecular characteristics, hosts and geographical origin, Mendes-Pereira et al (2003). divided the Leptosphaeria species complex into 7 groups: Leptosphaeria biglobosa brassicae, Leptosphaeria biglobosa canadensis, Leptosphaeria biglobosa erysimi, Leptosphaeria biglobosa thlaspii, Leptosphaeria biglobosa australensis, Leptosphaeria maculans brassicae, and Leptosphaeria maculans lepidii. The aim of this study was to perform a molecular analysis, identification of pathogenic fungus Leptosphaeria maculans and Leptosphaeria biglobosa in Serbia. 


\section{Material and Methods}

Fungal cultures were isolated from infected plant parts of oilseed rape, which were collected from 9 localities (Karavukovo, Crvenka, Prigrevica, Subotica, Rimski šančevi, Srbobran, Beška, Banatsko Karađorđevo, and Srpski Miletić) during 2008-2010. Tiny fragments were taken from the infected plant organs and immersed into a 3\% sodium hypochlorite solution for 3-5 minutes, and then washed with distilled water, and naturally dried under controlled conditions. After drying, fragments of infected tissue were poured in Petri dishes in a box, and placed on a nutrient medium e.g. Potato Dextrose agar (PDA) (Difco Detroit USA). In total, 119 isolates were identified. Isolates from Vojvodina were labelled K, C,L,S,St,GS,and Lj. Two more reference isolates were used in addition, which were received from the Agricultural research centre in Rothamsted UK, and labelled as L.m (Leptosphaeria maculans) and L.b (Leptosphaeria biglobosa).

\section{DNA extraction}

Mycelium fragments and picnides were scraped from the agar and placed into plastic baths. After grinding, $800 \mu \mathrm{l}$ CTAB buffer $(2 \%$ (w/v) CTAB $100 \mu \mathrm{l}$ Tris- $\mathrm{HCl} \mathrm{pH}$ 8,0, 20 mMEDTA pH 8,0,1,4 $\mathrm{MNaCl}$ and $1 \%(\mathrm{w} / \mathrm{v})$ polyvinyl-pyrrolidone) was added to the mixture, and transfered into $2 \mathrm{ml}$ test tubes. Tubes were placed in the incubator for $1 \mathrm{~h}$ at $65^{\circ} \mathrm{C}$, and each 15 minutes tube contents were vortexed for 5 mins. $600 \mu \mathrm{l}$ chloroform was added to the tubes after incubation, and vortexed in the incubator for $10 \mathrm{~s}$ at $25^{\circ} \mathrm{C}$. Tubes were then centrifuged for 10 mins at $1300 \mathrm{~g}$. Liquid phase (about 500 $\mu \mathrm{l})$ was transferred into new tubes, $300 \mu \mathrm{l}$ isopropanol was added, then it was incubated at room temperature and centrifuged for $10 \mathrm{mins}$ at $1300 \mathrm{~g}$. The liquid was poured out of the tubes after centrifuge, and $600 \mu \mathrm{l}$ of $70 \%$ ethanol was added. Tubes were vortexed in the incubator for $10 \mathrm{~s}$, centrifuged for $10 \mathrm{mins}$ at $1300 \mathrm{~g}$, and then liquid was removed from the tubes. Open tubes were placed in the drier for 10 mins at $50{ }^{\circ} \mathrm{C}$. The obtained residue was dissolved in a $25 \mu \mathrm{l} \mathrm{TE}$ buffer, $\mathrm{pH} 8$, and frozen at $-20^{\circ} \mathrm{C}$. DNA was extracted from all isolates using the same method (Day \& Shattock 1997).

\section{PCR analysis}

Two primers were used for DNA amplification - PN3 (5'CCGTTGGTGAACCAGCGGAGGGATC) and PN10(TCCGCTTATTGATATGCTTAAG), Balesdent et al. (1998). PCR reaction was performed at the total volume of $25 \mu \mathrm{l}$, containing: $1 \mu \mathrm{l}$ fungal (L. maculans and $\mathrm{L}$. biglobosa) DNA, $11 \mu \mathrm{l}$ PCR water, 12,5 $\mu \mathrm{l}$ master mix REDTaq (Sigma aldrich) with $\mathrm{MgCl} 2$ (Taq plimerase 0,06 $\mathrm{U} / \mu \mathrm{l} 3 \mathrm{mM} \mathrm{MgCl} 20,002 \%$ gelatine $0,4 \mathrm{mM} \mathrm{dNTP}$ ), and $1,25 \mu \mathrm{l}$ of each primer. The mixture was briefly centrifuged, and the tubes were placed in a PCR apparatus (Eppendorf master cycler gradient). Each cycle was carried out for $30 \mathrm{~s}$ at $94{ }^{\circ} \mathrm{C}, 30 \mathrm{~s}$ at $58{ }^{\circ} \mathrm{C}$, and $1 \mathrm{~min}$ at $72{ }^{\circ} \mathrm{C}$. In total, 37 cycles were performed. After the completed PCR reaction, fragments were visually observed on a 1,5\% agarose gel coloured with ethidium bromide.

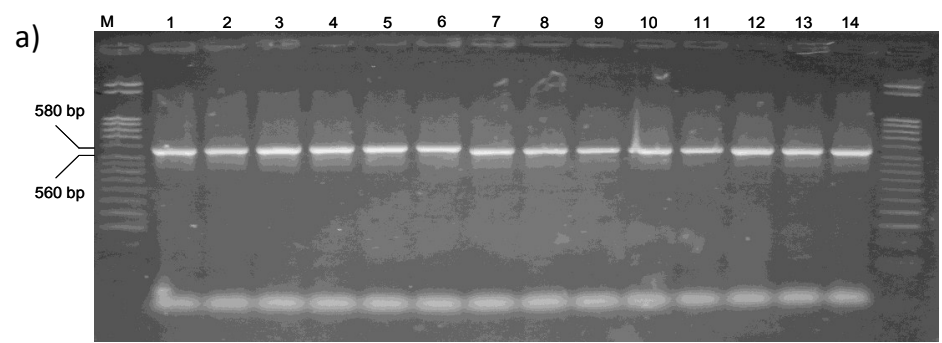

Figure 1a. Amplification with PN3 and PN10 primers. Band M 3000 bp marker, 1 L.b, 2 K-111, 3 K-112,4 K-113, 5 K-115, 6 K116, 7 K-2, 8 St-16, 9 GS-25, 10 L-5, 11 C-3, 12 Lj-2, 13 S-11, 14 L.m. 560 bp band was used for isolates L.m (reference isolate), K-2, St-16, GS-25, L-5, C-3, Lj-2, S-11, and 580 bp band for isolates L. b. (reference isolate) K-111, K-112, K-113, K-115, K-116.

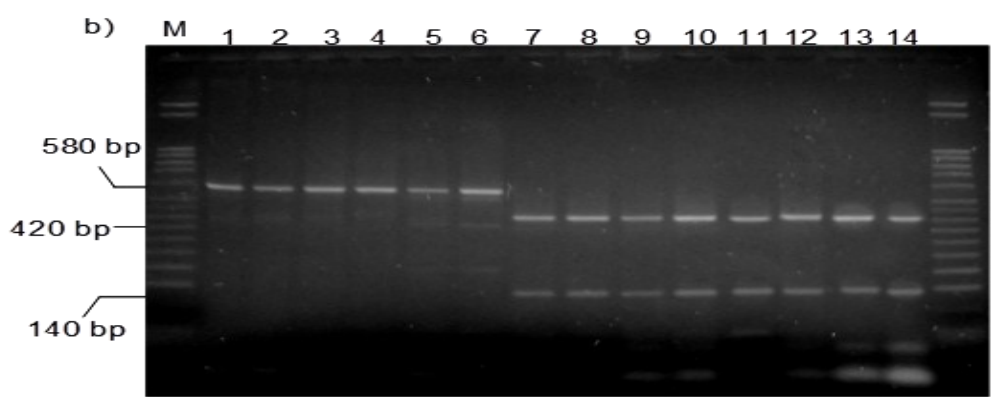

Figure 1b. Digestion of the amplified region with $\boldsymbol{B a m H I}$. Band M 3000 bp marker, 1 L.b, 2 K-111, 3 K-112,4 K-113, 5 K-115, 6 K-116, 7 K-2, 8 St-16, 9 GS-25, 10 L-5, 11 C-3, 12 Lj-2, 13 S-11, 14 L.m. Restriction enzyme BamHI in L.b, K-111, K-112, K113, K-115, and K-116 isolates cuts DNA at 580 bp, while in K-2, St-16, GS-25, L-5, C-3, Lj-2, S-11 and L.m. isolates DNA is cut at 420 and $140 \mathrm{bp}$. 


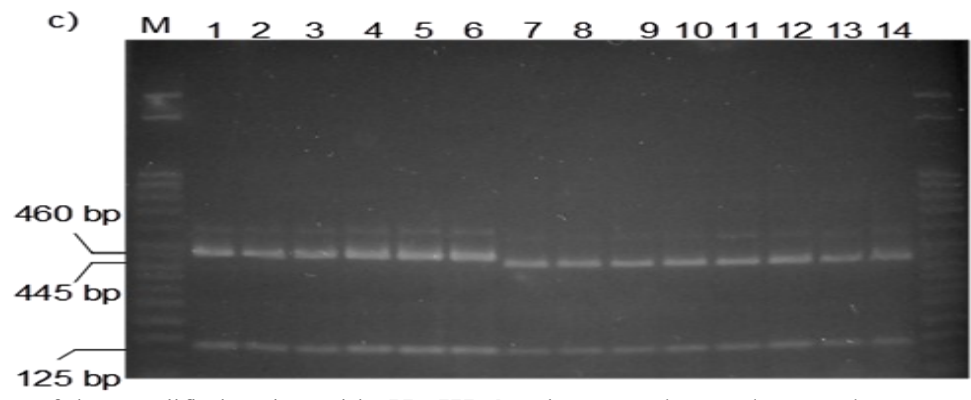

Figure 1c. Digestion of the amplified region with HaeIII. Band M 3000 bp marker, 1 L.b, 2 K-111, 3 K-112,4 K-113, 5 K-115, 6 K-116, 7 K-2, 8 St-16, 9 GS-25, 10 L-5, 11 C-3, 12 Lj-2, 13 S-11, 14 L.m. Restriction enzyme HaeIII in L.b, K-111, K-112, K113, K-115, and K-116 isolates it cuts DNA at 460 and 125 bp, while in K-2, St-16, GS-25, L-5, C-3, Lj-2, S-11 and L.m. isolates DNA is cut at 445 and $125 \mathrm{bp}$

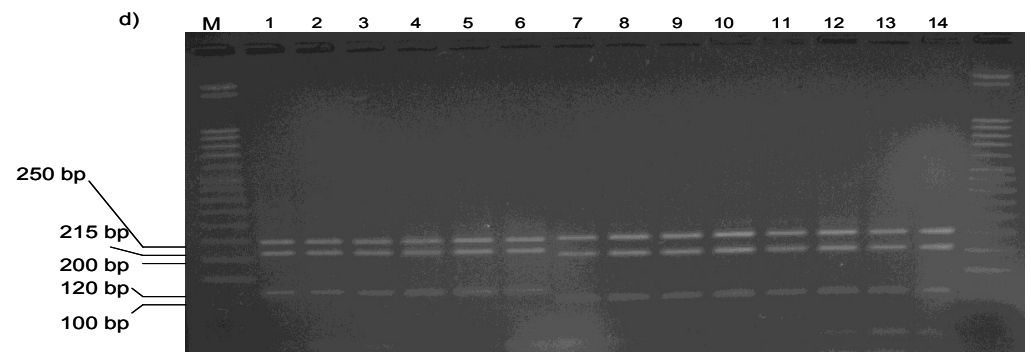

Figure 1d. Digestion of the amplified region with $\boldsymbol{R} \boldsymbol{s a I}$. Band M 3000 bp marker, 1 L.b, 2 K-111, 3 K-112,4 K-113, 5 K-115, 6 K -116, 7 K-2, 8 St-16, 9 GS-25, 10 L-5, 11 C-3, 12 Lj-2, 13 S-11, 14 L.m. Restriction enzyme RsaI in L.b, K-111, K-112, K-113, K -115 and K-116 isolates it cuts DNA at 120, 215 i 250 bp, while in K-2, St-16, GS-25, L-5, C-3, Lj-2, S-11, and L.m. isolates it cuts DNA at 100, 200 and 250 bp

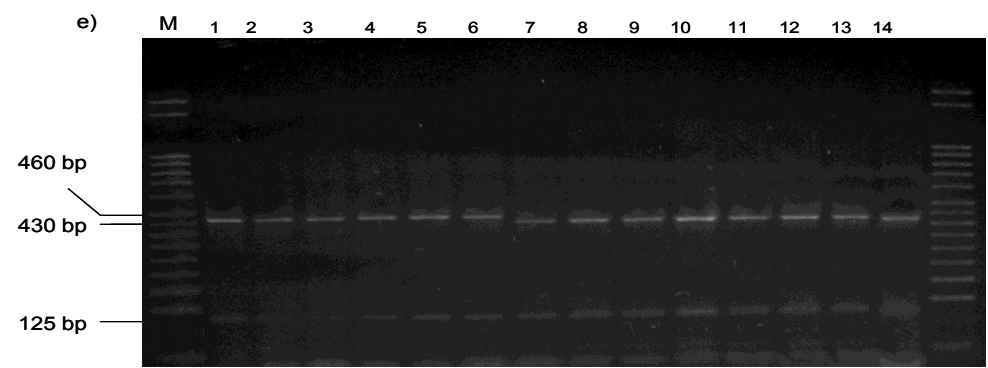

Figure 1e. Digestion of the amplified region with $\boldsymbol{E} \boldsymbol{c o R} \mathbf{R I I}$. Band M 3000 bp marker, 1 L.b, 2 K-111, 3 K-112,4 K-113, 5 K-115, 6 K-116, 7 K-2, 8 St-16, 9 GS-25, 10 L-5, 11 C-3, 12 Lj-2, 13 S-11, 14 L.m. Restriction enzyme EcoRII in L.b, K-111, K-112, K113, K-115, and K-116 it cuts DNA at 125 and 460 bp,while in K-2, St-16, GS-25, L-5, C-3, Lj-2, S-11 and L.m. isolates it cuts DNA at 125 and $430 \mathrm{bp}$

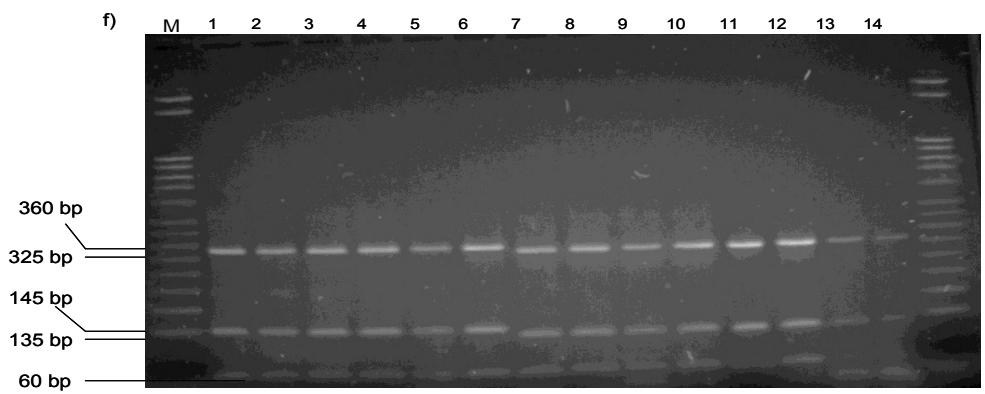

Figure 1f. Digestion of the amplified region with AluI. Band M 3000 bp marker, 1 L.b, 2 K-111, 3 K-112,4 K-113, 5 K-115, 6 K116, 7 K-2, 8 St-16, 9 GS-25, 10 L-5, 11 C-3, 12 Lj-2, 13 S-11, 14 L.m. Restriction enzyme AluI in L.b, K-111, K-112, K-113, K115, and K-116 it cuts DNA at 60, 145 and 360 bp, while in K-2, St-16, GS-25, L-5, C-3, Lj-2, S-11 and L.m. isolates it cuts DNA at 60,135 and $325 \mathrm{bp}$ 


\section{PCR-RFLP analysis}

The following isolates were used for the PCR-RFLP analysis: L.b (reference isolate $L$. biglobosa) K-111, K112, K-113, K-115, K-116, K-2, St-16, GS-25, L-5, C-3, Lj-2, S-11, and L.m. (reference isolate L. maculans).

PCR-RFLP was conducted following the producer's recommendations (Fermentas life science) according to Balesdenet et al. 1998. Ten microlitres of PCR product, obtained in the use of PN3 and PN10 primers, were digested in $5 \mathrm{~h}$ at $37^{\circ} \mathrm{C}$ of $20 \mathrm{U}$ with one of the following enzymes: BamHI, HaeIII, RsaI, EcoRII and AluI. After incubation restriction fragments were observed in a 1,5\% agarose gel coloured with $20 \mu \mathrm{l}$ ethidium bromide. Isolates were randomly selected for this analysis. Isolates K-2, St-16, GS-25, L-5, C-3, Lj-2, and $\mathrm{S}-11$ represented a group in these testings, i.e. a plant organ which they were isolated from. Five out of 8 isolates were used for RFLP analysis, labelled K-111, $\mathrm{K}-112$, etc. Given that these 8 isolates showed great morphological similarities with the reference isolate L.b, 5 isolates were used in the PCR-RFLP analysis, in order to identify which subgroup NA-1, NA-2 or NA3 L. biglobosa isolates from Serbia belong to.

\section{Results and Discussion}

Based on PCR-RFLP analysis, all tested isolates from Serbia (K-111, K-112, K-113, K-115, and K-116) as well as the reference isolate L.b. belong to Leptosphaeria biglobosa species - NA 1 subgroup, while K2, St-16, GS-25, L-5, C-3, Lj-2, S-11, also from Serbia, and the reference isolate L.m. belong to Leptosphaeria maculans species. Tape lengths are expressed in bp (base pairs). PN3 and PN10 primers of tested isolates amplify DNA at 560 bp for Leptosphaeria maculans species, and 580 bp for Leptosphaeria biglobosa, which is in accordance with Balesdent et al. (1998). Mendes-Pereira et al. (2003) reported 468 bp for Leptosphaeria maculans species (Tox + representative isolates) and 496 bp for Leptosphaeria biglobosa species NA1, NA2, and NA3 subgroup. Liu et al. (2006), and Fernando et al. (2016) reported 331-bp L.maculans 'brassicae' isolates and a 444bp product from L. biglobosa'brassicae' isolates. Based on the RFLP profile, these reported species can also be identified. Restriction enzyme EcoRI cuts DNA at 430 bp in agressive isolates (Leptosphaeria maculans), while in non-agressive isolates (Leptosphaeria biglobosa) this fragment was not observed (Koch et al. 1991). The obtained polymorphism enabled identification of tested isolates from Serbia by the use of restriction enzymes. Thus isolates $\mathrm{K}-111, \mathrm{~K}-112, \mathrm{~K}-113, \mathrm{~K}-115$, and $\mathrm{K}-116$ belong to Leptosphaeria biglobosa species, while K-2, St-16, GS-25, L-5, C-3, S-11, Lj-2 belong to Leptosphaeria maculans species. Besides separating the isolates according to species, polymorphism obtained by restriction enzymes HaeIII, EcoRII and AluI all tested isolates (K-111, K-112, K-113, K-115 and K-116) belong to Leptosphaeria biglobosa species, subgroup NA1 dominant in Europe (Gall et al. 1995, Jedryczka et al. 1999, Fitt et al. 2006), which is in accordance with the results (Balesdent et al. 1998).

\section{Conclusions}

Based on DNA amplification with PN3 and PN10 primers, K-111, K-112, K-113, K-114, K-115, K-116, K -117 and $\mathrm{K}-118$ are amplified at 580 bp band, while other isolates (K-1 do K-25, St-1 do St-28, GS-1 do GS27, C-1 do C-6, L-1 do L-10, S-1 do S-11, Lj-1 to Lj-6) are amplified at 560 bp band.In RFLP analysis K-111, $\mathrm{K}-112, \mathrm{~K}-113, \mathrm{~K}-115$ and $\mathrm{K}-116$ are different in one or two restriction sites of K-2 St-16 GS-25 L-5 C-3 Lj-2 and S-11 isolates. Based on the conducted research, we can conclude that isolates K-111, K-112, K-113, K-114, $\mathrm{K}-115, \mathrm{~K}-116, \mathrm{~K}-117$, and K-118 belong to Leptosphaeria biglobosa subgroup NA1 according to the new classification of Leptosphaeria biglobosa brassicae, while K-1 to K-25, St-1 to St-28, GS-1 to GS-27, C-1 to C-6, L-1 to $\mathrm{L}-10, \mathrm{~S}-1$ to $\mathrm{S}-11$, and $\mathrm{Lj}-1$ to $\mathrm{Lj}-6$ belong to Leptosphaeria maculans according to the new classification of Leptosphaeria maculans brassicae. After the completion of this research, we can conclude that both species present in Serbia (Leptosphaeria maculans and Leptosphaeria biglobosa) are causal agents of stem canker of oilseed rape (Brassica napus var. oleifera $\mathrm{L}$ ).

\section{References}

Aubertot, J. N., West, S., Bousset-Vaslin, L., Salam, M. U., Barbetti, M. J., Diggle, A. J. (2006): Improved resistance management for durable disease control: a cas study of Phoma stem canker of oilseed rape (Brassica napus). Eur. J. Plant Pathol. 114: 91-106.

Badawy, H. M. A., Hoppe, H. H. (1989): Production of Phytotoxic Sirodesmins by Aggressive Strains of Leptosphaeria maculans Differing in Interactions with Oil Seed Rape Genotypes J. Phytopathology 127: 146-157.

Balesdent, M. H., Gall, C., Robin, P., Rouxel, T. (1992): Interspecific variation in saluble mycelial protein and esterase patterns of Leptospheria maculans French isolates. Mycological Research 96: 677684.

Balesdent, M. H., Jedryczka, M., Jain, L., Mendes-Pereira, E., Bertrandy, J., Rouxel, T. (1998): Conidia as a substrate for internal transcribed spacer-based PCR identification of components of the Leptosphaeria maculans species complex. Phytopathology 88: 1210-1217.

Brun, H., Levivier, S., Eber, F., Renard, M., Chevre, A. M., (1997): Electrophoretic analysis of natural populations of Leptospheria maculans directly from leaf lesions. Plant Pathology 46 147-154.

Day, J. P., Shattock, R. C., (1997): Aggressiveness and other factors relating to displacement of populations of Phytophtora infestans in England and Wales. European Journal of Plant Pathology 103 379391.

Fernando, W. G. D., Zhang, H., Amarasinghe, C. C., (2016):Detection of Leptosphaeria maculans and Leptosphaeria biglobosa causing blaklag disease in canola from Canadian canola seeds lots and dockage. Plants 5, 12; doi:10.3390/plants5010012.

Fitt, B. D. L., Brun, H., Barbetti, J. M., Rimmer, R. S. (2006): Worldwide importance of phoma stem canker (Leptospheria maculans and L. biglobosa) on oilseed rape (Brassica napus). European Journal of Plant Pathology 114: 3-15.

Gabrielson, R. L., (1983): Blackleg disease of crucifers caused by Leptospheria maculans (Phoma lingam) and its control. Seed Science and Technology. 11: 749-780.

Gall, C., Balesdent, M. H., Desthieux, I., Robin, P., Rouxell, T., (1995): Polymorphism of $\operatorname{Tox}^{0}$ Leptospheria maculans isolates as revealed by 
soluble protein and isozyme electrophoresis. Mycological Research 99 221-229.

Gosende, S., Penaud, A., Aubertat, J. N., Schnieder, O., Pinochet, X., (2003): Evolution of soil surface oilseed rape stubbles and their ability to produce spores of Leptosphaeria maculans.preliminary results 11th International Rapeseed CongressProceeding 41166-1168 Denmark.

Howlett, B. J. (2004): Current knowledge of the interactio between Brassica napus and Leptosphaeria maculans. Can. J. Plant Pathol. 26: 245-252.

Howlett, B. J., Idnurm, A., Pedras, M. S. C. (2001): Leptosphaeria maculans the causal agent of blackleg disease of Brassicas. Fungal Genet. Biol. 33: $1-14$.

Huang, Y. J., Fitt, B. D. L., Jedruczka, M., Dakowska, S., West, J. S., Gladders, P., Steed, J. M., Li, Z. Q. (2005): Patterns of ascocpora release in relation to phoma stem canker epidemiology in England (Leptosphaeria maculans) and Poland (L. biglobosa). European Journal of Plant Pathology 111: 263-277.

Jedryczka, M., Rouxel, T., Balesdent, M. H. (1999): Rep-PCR based genomic fingerprinting of isolates of Leptosphaeria maculans from Poland. European Journal of Plant Pathology. 105: 813-823.

Johnson, R. D., Lewis, B. G. (1990): DNK polymorphism in Leptosphaeria maculans. Physiological and Molecular Plant Pathology 37: 417-424.

Koch, E., Badaway, A. M. H., Hope, H. H. (1989): Differences between aggressive and non aggressive single spore lines of Leptospheria maculans in cultural characteristics and phytotoxin production. J. Phytopathol. 124: 52-62.
Koch, E., Song, R., Osborn, C. T., Williams, P. H. (1991): Relationship between pathogenicity and phylogeny based on restriction fragment lenght polimorphism in Leptospheria maculans. Molecular PlantMicrobe Interactions 4: 341-349.

Liu, S. Y., Liu, Z., Fitt, B. D. L., Evans, N., Forster, S. J., Huang, Y. J., Latunde-Dada, A. O., Lucas, J. A. (2006): Resistance to Leptosphaeria maculans (phoma stem canker) in Brassica napus (oilseed rape) induced by L. biglobosa and chemical defence activators in field and controlled environments. Plant Pathol. 55, 401-412.

McGee, D. C., Petrie, G. A. (1978): Variability of Leptospheria maculans in relation to blackleg of oilseed rape. Phytopathology 68: 625-630.

Mendes-Pereira, E., Balesdent, M. H., Brun, H., Rouxel, T., (2003): Molecular phylogeny of the Leptosphaeria maculans - Leptosphaeria biglobosa species complex. Mycol. Res. 107 (11): 1287-1304.

Mitrović, P. M., Orčić, D. Z., Sakač, Z. O., Marjanović-Jeromela, A. M., Grahovac, N. L., Milošević, D. M., Marisavljević, D. P., (2012): Characterization of sirodesmins isolated from the phytopathogenic fungus Leptosphaeria maculans.J.Serb.Chem.Soc.77(10)1363-1379.

Paul, V., Rowlinson, C. J. (1992): Diseases and pests of rape. Verlag Theodore Mann Gelsenkirchen- Buer Germany.

Sosnowski,M. R., Scott, E. S., Ramsey, M. D. (2004): Infection of Australian canola cultivars (Brassica napus) by Leptospheria maculans is influenced by cultivar and environmental conditions. Australas. Plant Pathol. 33: 401-411.

Williams, H. R., Fitt, B. D. L. (1999): Differentiating A and B groups of Leptospheria maculans casual agent of stem canker (blackleg) of oilseed rape. Plant Pathology 48, 161-175.

\section{Molekularna karakterizacija i identifikacija gljiva uzročnika raka stabla uljane repice u Srbiji}

\section{Petar Mitrović · Ana Marjanović Jeromela · Željko Milovac · Velimir Radić}

Sažetak: Kulture gljiva izolovane su iz obolelih biljnih delova uljane repice koji su prikupljeni iz devet lokaliteta (Karavukovo, Crvenka, Prigrevica, Subotica, Rimski šančevi, Srbobran, Beška, Banatsko Karađorđevo, Srpski Miletić) u periodu od 2008 do 2010. godine. Uzorci obolelog tkiva su uzeti sa korena, prizemnog stabla, gornjeg dela stabla i grana, kao i sa lista, cveta, ljuski i semena. Molekularna karakterizacija je sprovedena korišćenjem lančane reakcije polimeraze PCR i PCR-RFLP, a ukupno je ispitivano 119 izolata poreklom iz Srbije i dva referentna izolata iz Velike Britanije. Digestija PCR produkata je sprovedena sa 5 odabranih endonukleaza: BamHI, HaeIII, RsaI, EcoRII i $A l u I$. $\mathrm{Na}$ osnovu PCR analize, svi izolati poreklom iz Srbije pripadaju L. kompleksu: 111 pripada vrsti Leptosphaeria maculans, a 8 vrsti Leptosphaeria biglobosa NA1 (Leptosphaeria biglobosa brassicae)

Ključne reči: Brassica napus, endonukleaze, izolati, Leptosphaeria maculans, Leptosphaeria biglobosa, lokalitet, PCR and PCR -RFLP. 